\title{
Interaction of sinking behaviour of Saharan dust and lithogenic and biogenic fluxes in the Canary Basin
}

\author{
Maite Báez-Hernández ${ }^{1}$, Noemí García ${ }^{1}$, Inmaculada Menéndez ${ }^{1,2}$, Alfredo Jaramillo ${ }^{3,1}$, \\ Isora Sánchez-Pérez ${ }^{1}$, Ángelo Santana ${ }^{4}$, Ignacio Alonso ${ }^{1}$, José Mangas ${ }^{1,2}$, \\ Santiago Hernández-León ${ }^{1,2}$
${ }^{1}$ Instituto Oceanografía y Cambio Global, IOCAG, Universidad de Las Palmas de Gran Canaria 35017, Islas Canarias, España.
(MB-H) E-mail: maite.baez101@alu.ulpgc.es. ORCID iD: https://orcid.org/0000-0003-2108-5739
(NG) E-mail: noemi.garcia106@alu.ulpgc.es. ORCID iD: https://orcid.org/0000-0002-1731-3885
(IS-P) E-mail: isora.sanchez@uv.es. ORCID iD: https://orcid.org/0000-0001-9559-8786
(IA) E-mail: ignacio.alonso.bilbao@ulpgc.es. ORCID iD: https://orcid.org/0000-0002-9663-0773
(JM) E-mail: jose.mangas@ulpgc.es. ORCID iD: https://orcid.org/0000-0002-3286-743X
(SH-L) E-mail: shernandezleon@ulpgc.es. ORCID iD: https://orcid.org/0000-0002-3085-4969
${ }^{2}$ Instituto Oceanografía y Cambio Global, IOCAG, Universidad de Las Palmas de Gran Canaria, ULPGC, Unidad Asociada ULPGC-CSIC, Las Palmas de Gran Canaria, Spain.
${ }^{3}$ Grupo de Estudios Oceánicos "Luis Fernando Vásquez-Bedoya" (GEOc), Escuela Ambiental, Facultad de Ingeniería, Universidad de Antioquía UdeA, Medellín, Colombia.
(AJ) E-mail: alfredo.jaramillov@udea.edu.co. ORCID iD: https://orcid.org/0000-0002-4901-0416
${ }^{4}$ Departamento de Matemáticas, Universidad de Las Palmas de Gran Canaria 35017, Islas Canarias, España.
(AS) E-mail: angelo.santana@ulpgc.es. ORCID iD: https://orcid.org/0000-0002-6513-4814 \\ (IM) (Corresponding author) E-mail: inmaculada.menendez@ulpgc.es. ORCID iD: https://orcid.org/0000-0002-1801-5177
}

\begin{abstract}
Summary: Saharan dust events are currently the predominant source of lithogenic particles in the Canary Basin. In order to quantify this input and its relationship with the biogenic fluxes, a sediment trap was deployed in a free-drifting system a $150 \mathrm{~m}$ depth, $50 \mathrm{~km}$ off the north coast of Gran Canaria (Canary Islands). The mineralogy of the lithogenic particles included illite, calcite, hematite quartz, barite and kaolinite. The biogenic matter was composed of chitin, transparent exopolymer particles, and carbonates from foraminifera and gastropod shells. The average Saharan dust flux over the ocean surface was approximately $5 \pm 4 \mathrm{mg} \mathrm{m}^{-2} \mathrm{day}^{-1}$. The lithogenic, carbonate and chitin fluxes were $0.8 \pm 0.6,6.0 \pm 7.4$ and $154 \pm 386 \mathrm{mg} \mathrm{m}^{-2}$ day $^{-1}$, respectively. A fairly strong Saharan dust event during sampling was observed in the trap, with a delay of three days in the peaks of lithogenic and biogenic fluxes. The theoretical settling velocity of the lithogenic particles associated with Saharan dust events at $150 \mathrm{~m}$ depth was $\mathrm{v}_{\text {Stokes }}=275 \mathrm{~m} \mathrm{day}^{-1}$, and the experimental settling was about $50 \mathrm{~m} \mathrm{day}^{-1}$. The associated sinking behaviour of particulate organic carbon and biogenic and lithogenic fluxes observed in this study may contribute to a more realistic prediction of these fluxes in carbon biological pump models.
\end{abstract}

Keywords: lithogenic flux; biogenic flux; POC flux; TEP; image analysis; Saharan dust; Canary Basin.

Interacción sedimentaria del polvo sahariano, y los flujos biogénicos y litogénicos en la cuenca oceánica de Canarias

Resumen: En la actualidad los eventos de polvo Sahariano son la fuente principal de partículas litogénicas en la cuenca oceánica de Canarias. Con el objetivo de cuantificar su entrada y la interacción con los flujos biogénicos, se instaló una trampa de sedimento a la deriva, a $150 \mathrm{~m}$ de profundidad, $50 \mathrm{~km}$ al norte de la costa de Gran Canaria (Islas Canarias). Las partículas litogénicas detectadas fueron de illita, calcita, hematites, cuarzo, barita y caolinita. El material biogénico estaba compuesto por quitina, partículas de exopolímeros transparentes (TEP) y carbonatos procedentes de foraminíferos y conchas de gasterópodos. La media del flujo de polvo sahariano sobre la superficie oceánica fue aproximadamente $5 \pm 4 \mathrm{mg} \mathrm{m}^{-2} \mathrm{dia}^{-1}$. Las medias de flujos litogénico, carbonato y quitina respectivamente fueron $0.8 \pm 0.6 \mathrm{mg} \mathrm{m}^{-2} \mathrm{dia}^{-1}, 6.0 \pm 7.4 \mathrm{mg} \mathrm{m}^{-2} \mathrm{dia}^{-1} \mathrm{y}$ $154 \pm 386 \mathrm{mg} \mathrm{m}^{-2} \mathrm{dia}^{-1}$. Durante el muestreo se registró un intenso evento de polvo sahariano seguido, a los tres días, de picos en los flujos litogénicos y biogénicos en la trampa de sedimento a $150 \mathrm{~m}$ de profundidad. La velocidad teórica de sedimentación de las partículas litogénicas asociadas a los eventos de polvo sahariano a $150 \mathrm{~m}$ de profundidad calculada fue de $\mathrm{v}_{\mathrm{Stakes}}=275 \mathrm{~m} \mathrm{dia}^{-1}$, siendo la velocidad de sedimentación experimental obtenida tras el análisis de los flujos fue de $50 \mathrm{~m} \mathrm{dia}^{-1}$. El comportamiento de los procesos de sedimentación asociados al POC, el flujo biogénico y el flujo litogénico observados en este estudio podría contribuir a modelos más realistas de la bomba biológica de carbono en los océanos.

Palabras clave: flujos litogénicos; flujos biogénicos; flujos POC; TEP; análisis de imagen; polvo sahariano; cuenca oceánica de Canarias. 
Citation/Como citar este artículo: Báez-Hernández M., García N., Menéndez I., Jaramillo A., Sánchez-Pérez I., Santana A., Alonso I., Mangas J., Hernández-León S. 2019. Interaction of sinking behaviour of Saharan dust and lithogenic and biogenic fluxes in the Canary Basin. Sci. Mar. 83(2): 000-000. https://doi.org/10.3989/scimar.04877.19A

Editor: F. Peters.

Received: October 11, 2018. Accepted: February 20, 2019. Published: May 7, 2019.

Copyright: (C) 2019 CSIC. This is an open-access article distributed under the terms of the Creative Commons Attribution 4.0 International (CC BY 4.0) License.

\section{INTRODUCTION}

Lithogenic particles enter the marine environment through either fluvial or aeolian transport. Fluvial processes produce by far the largest amount of mineral input into the oceans (Milliman and Syvitski 1992), but the contribution of aeolian processes to sediment flux in the deep sea is significantly higher, since fluvial transported material is mainly restricted to continental shelves (Sarnthein et al. 1982). In the Canary Basin, the main source of aeolian input is dust from the Saharan desert. Dust particles are subject to ageing and mixing processes throughout their atmospheric lifetime. The ageing of dust takes place after long-range transport in air, involves surface chemical reactions with gases such as $\mathrm{NO}_{2}, \mathrm{SO}_{2}, \mathrm{HNO}_{3}, \mathrm{O}_{3}$ (Astitha et al. 2010), and may also involve mixing with maritime particles and/ or anthropogenic pollution (Ansmann et al. 2008). The dry climate of the area and the seasonal presence of the Saharan Air Layer in the Canary Basin promotes a connection between the Sahara Desert and the Canary Current in terms of lithogenic input (Menéndez et al. 2017). Here, as in many regions of the ocean, lithogenic matter is a major component of particle flux moving towards the deep sea (Ratmeyer et al. 1999), so studying its role in the carbon pump is of paramount importance. Post-depositional processes begin at the ocean surface (de Leeuw et al. 2014), where lithogenic particles enter the organic micro-layer at the sea's surface, favouring aggregate formation. Dust deposition is a key process for marine biota, because it transports significant amounts of iron. This metal is found in silicates and iron oxy-hydroxide forms of the Saharan plume dust reaching the ocean surface (Journet et al. 2008, Engelbrecht et al. 2014). This dust input increases biomass and metabolic activity (Hernández-León et al. 2004, 2007, Herrera et al. 2017), and has a considerable ballast effect on particulate organic carbon (POC) flux (Mari et al. 2017, van der Jagt et al. 2018).

Particulate organic matter in the ocean is composed of living organisms and non-living organic matter (detritus), the latter being the bulk in terms of carbon (Dong et al. 2010). The composition of this matter is closely related to the plankton community structure. Among the particulate components are diverse microplanktonic organisms such as coccolithophorids (Sprengel et al. 2000), diatoms (Huskin et al. 2004, Anabalón et al. 2014), foraminifera (Elder et al. 2018), and mesoplanktonic animals such as crustaceans and mollusca (e.g. gastropods). Both communities produce shells of carbonate (coccolithophorids, foraminifera), silica (diatoms), or chitin as exoskeletons (crusta- ceans). Transparent exopolymer particles (TEPs) and faecal matter are also components of particulate organic carbon (POC). The former are composed of extracellular polymeric substances exuded by microorganisms (Alldredge et al. 1993), while the latter are mainly produced by mesoplanktonic, macroplanktonic (Turner 2015), and micronektonic (Røstad and Kaartvedt 2013, Ariza et al. 2015) organisms, transporting a fraction of their ingested matter. These compounds are thus all expected to sink together with the mineral and organic particles deposited on the ocean during dust events such as those seen in the Canary Current due to the proximity of the Sahara desert.

The biological pump is a principal means of vertical transport of carbon in the ocean, and the sinking of POC is one of its main components (Buesseler et al. 2007). The interaction between lithogenic particles from a dusty provenance and POC is of paramount importance for studying the way the different materials leave the epipelagic zone. Lithogenic material can be incorporated into organic aggregates (POC and TEP), acting as ballast, increasing sinking, and enhancing the carbon exported to the mesopelagic zone (van der Jagt et al. 2018). Van der Jagt et al (2018) have suggested that carbon exported in areas of high dust deposition is strongly controlled by dust on the ocean surface together with TEP abundance.

The formation of large amorphous aggregates in the ocean water column, consisting of a mixture of organic and inorganic matter, the so-called "marine snow", may accelerate (Alldredge and Silver 1988) or reduce the theoretical flux of different particles, depending on their different density. Passow (2000) suggested that the POC flux is accelerated by the ballast effect of minerals particles. Marine snow also aggregates scavenged mineral particles. For instance, off the Mauritanian coastal upwelling (Cape Blanc), the summer coccolithophorid bloom produced particle sinking rates of up to almost $570 \mathrm{~m}$ per day, transporting high amounts of organic carbon to the deep ocean (Fischer and Karakas 2009). However, there is no straightforward relationship between carbonate content and particle sinking, nor noticeably higher sinking rates in dust-rich ocean regions off NW Africa (Fischer and Karakas 2009). Further mesocosms studies in the Mediterranean areas intensely affected by Saharan dust input found that lithogenic fluxes explained more than $85 \%$ of the variance in POC fluxes, using linear regressions, and suggested that a major component of the biological pump in oceanic areas exposed to strong atmospheric forcing might be the lithogenic carbon pump (Bressac et al. 2014). 


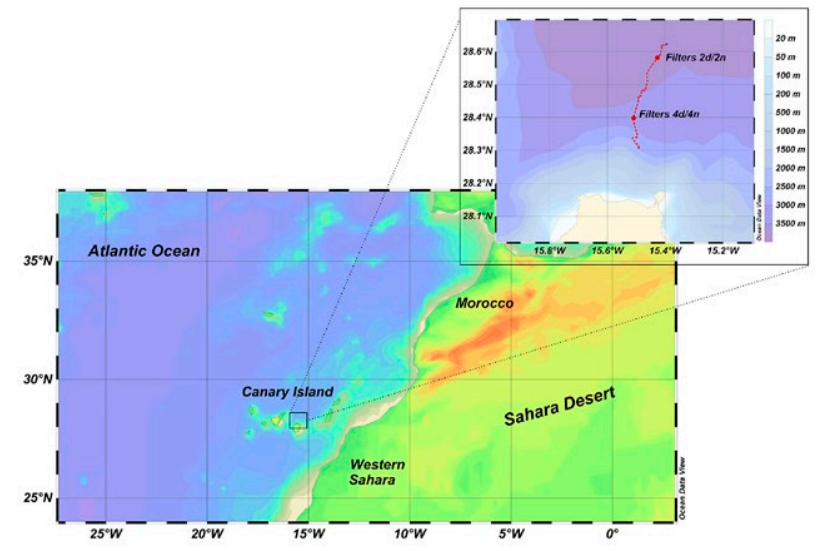

Fig. 1. - Location of the study site north of the Canary Islands. Red dotted line shows the path followed by the drifting sediment trap, moving from $\mathrm{N}$ to $\mathrm{S}$.

The joint study of lithogenic material and POC could therefore contribute to our understanding of carbon transport in the ocean. The aim of the present study was thus to identify and quantify lithogenic and biogenic fluxes on a daily basis through image analysis of particles collected in sediment traps at $150 \mathrm{~m}$ depth in the Canary Basin, to examine their relationship with Saharan dust input to the ocean surface, and to study the interaction between their sinking behaviour.

\section{MATERIALS AND METHODS}

\section{Sampling}

Oceanic samples were collected at $150 \mathrm{~m}$ depth using a PPS3/3-24 S time-series sediment trap with a sampling area of $0.125 \mathrm{~m}^{2}$ and a sampling frequency of 12 hours. Half the samples were taken in diurnal periods, from 6 a.m. to 6 p.m. (UTC, solar time), and the other half in nocturnal periods, from 6 p.m. to 6 a.m. The sediment trap array was deployed twice, the first time from 2 to 6 April 2011, and then from 7 to 13 April 2011. No samples were collected on 6 April 2011 because the day was used for the collection procedure and the new deployment. The sediment trap was installed as a free-drifting system, initially located at a distance of nearly $50 \mathrm{~km}$ north of Gran Canaria Island (Fig. 1). The samples were filtered just after collection, using a glass fibre filter (GF/C) with a pore size of $1.4 \mathrm{~mm}$ to avoid possible silica dissolution (Bauerfeind and Bodungen 2006). The filters were split in two, one for lithogenic and biogenic particles and the other for POC analysis. The filters used for lithogenic and biogenic quantification were treated with hydrogen peroxide $(3 \%)$ previously heated to $50^{\circ} \mathrm{C}$ in order to eliminate organic matter. Gelatinous matter agglutinating particles persisted after treatment. This gelatinous matter had a similar visual aspect to other transparent masses observed by other authors (Martinez-Ruiz et al. 2019) and defined as TEPs (Alldredge et al. 1993, Passow 2002, Mari et al. 2017). Mineralogical determination of lithogenic particles was implemented using scanning electron microscopy/energy dispersive x-ray spectroscopy (SEM-EDX) at the Microscopy Service of the University of Huelva, Spain. The filter fractions used for POC analysis were wrapped in pre-combusted aluminium foil and frozen at $-20^{\circ} \mathrm{C}$ until laboratory determination using a CHN analyser (Carlo Erba EA 1108 Elemental), according to procedures described by Alonso-González et al. (2010a). Swimmers (zooplankton entering the trap, Michaels et al. 1988) larger than approximately $1 \mathrm{~mm}$ were manually removed under a stereoscopic microscope. Dust events were identified using the dust load charts provided by the DREAM forecasting model at $0.0 \mathrm{~h}$ (Pérez et al. 2011, Haustein et al. 2012, Fig. 2). The DREAM prediction model of the Saharan plume dust also showed real time information at $0.0 \mathrm{~h}$ jointly with meteorological data; the daily operational model evaluation included satellites (MODIS and MSG) and Aerosol Robotic Network (AERONET) sun photometers (Basart et al. 2012). This real time information (expressed in dust concentration and flux) was used in this study.

The recorded Saharan dust period was from 30 March to 12 April (Fig. 2). Two Saharan dust plumes were observed during the sediment trap sampling period (Figs 2 and 3). The first and most intense was from 3 March to 3 April, with a peak of $15 \mathrm{mg} \mathrm{m}^{2}$ day $^{-1}$, and a second dust plume was recorded from the second half of 6 April to the first half of 8 April, showing a peak of $1.5 \mathrm{mg} \mathrm{m}^{2} \mathrm{day}^{-1}$. At the peak of lithogenic flux (2 April), there was no Saharan dust in the atmosphere. The dust input to the ocean was in dry deposition excepting a small amount of rain, $0.2 \mathrm{~mm}$, on 2 April (source: automatic station C659M-Plaza de la Feria, City of Las Palmas de Gran Canaria, from the Spanish meteorology state agency, AEMET).

\section{Image analysis}

Images from the filters were obtained with a Leika@ MZ6 stereoscopic microscope equipped with a photographic camera. They were taken at a resolution of 5.0 megapixels, illuminated by multiple nonpolarizing natural light foci in order to avoid shadows. An $8 \times$ zoom and a grid of $4 \mathrm{~mm}$ were used to scan the whole filter, taking photographs in each grid area. A set of 396 images were obtained in total, at about 22-27 images for each filter. The image analysis was designed to guarantee a standard process for each filter. Firstly, the threshold for each picture was adjusted using the Corel PaintShop program. Brightness and contrast levels were established using a lens in order to minimize the background noise. Scaling of the images was performed using ImageJ software and the ratio between pixel size and the actual dimensions of the grid was measured. Each particle, agglomerate and biogenic formation was identified as irregular polygons, thus allowing their morphometric characteristics to be easily obtained. For a better discrimination between the background and particles, the images were binarized from RGB to black and white. The error uncertainty of the image treatment measurements is the pixel size $(2 \mathrm{~mm})$. No particles below this size were measured. 

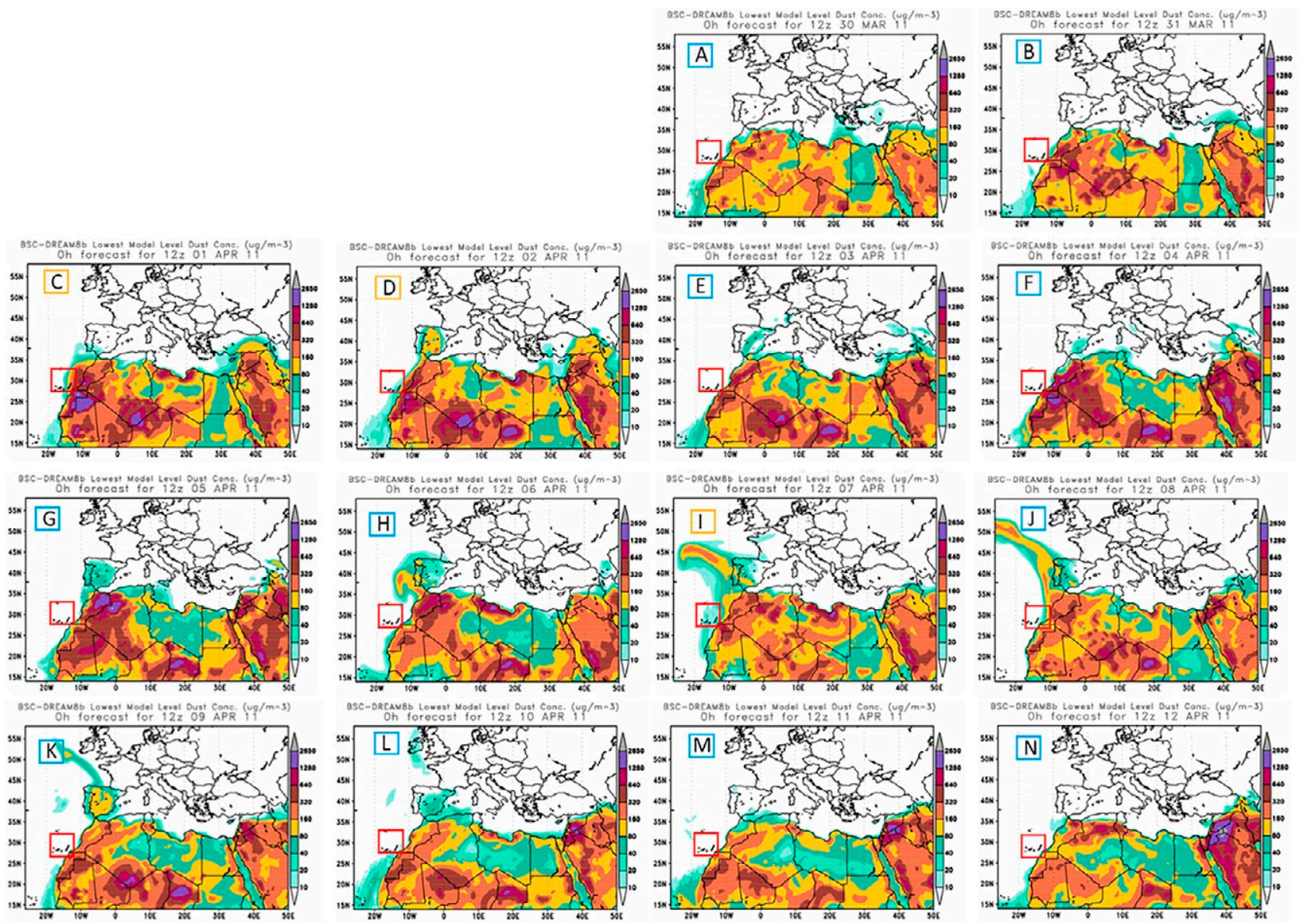

Fig. 2. - Saharan plume dust diary charts for the entire study period, provided by the BSC-DREAM forecasting model within direct measurement, at $0 \mathrm{~h}$ (https://sds-was.aemet.es/forecast-products/dust-forecasts/forecast-comparison). Pale yellow squares (C, D, I) are the Saharan plume dust days; blue squares are all non-Saharan dust days. The red square indicates the location of the stu dy site.

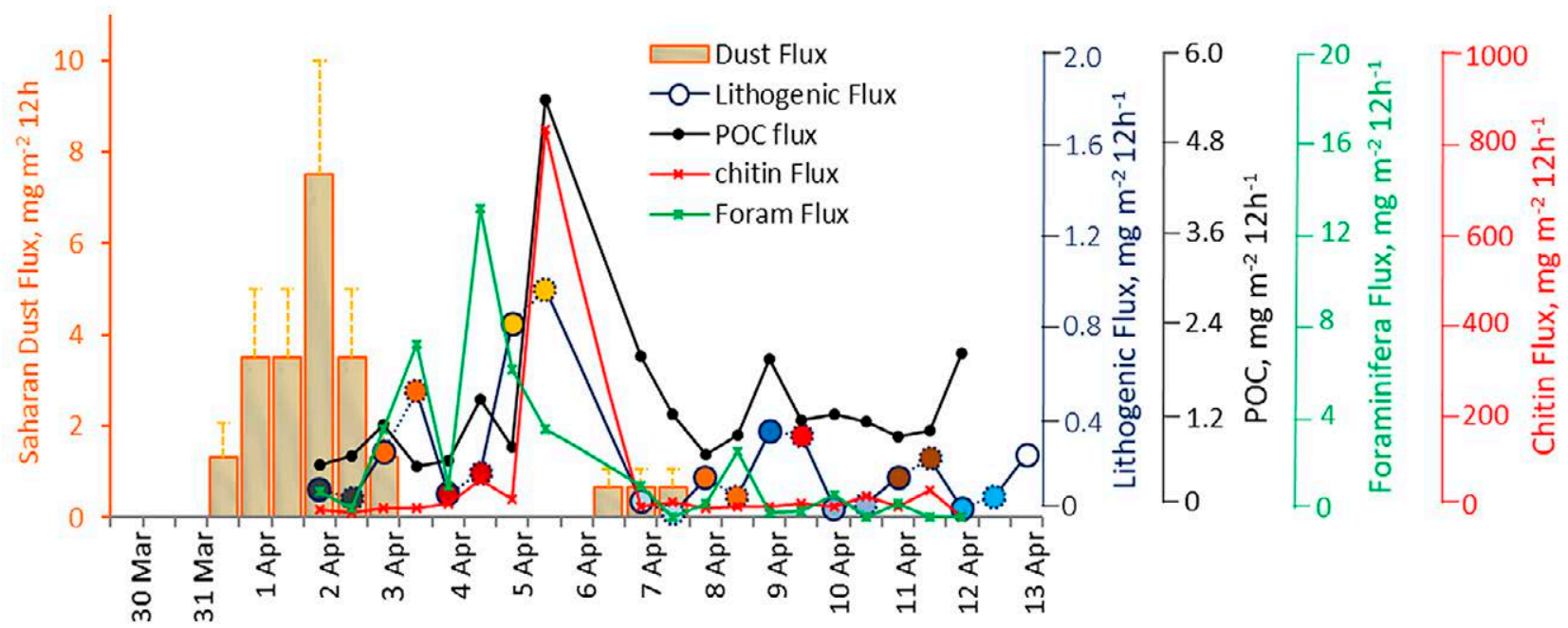

Fig. 3. - Saharan dust, lithogenic, POC chitin, and foraminifera fluxes in $\mathrm{mg} \mathrm{m}^{-2} 12 \mathrm{~h}^{-1}$ collected by the sediment trap at $150 \mathrm{~m}$ depth during the study period. The fill colour of the lithogenic points corresponds to those used in the legend for Figure 4.

This uncertainty is similar to the filter procedure, in which particles smaller than the filter voids would be lost during sample filtering. We observed no particles smaller than $2 \mathrm{~mm}$ in the SEM analyses performed on selected samples.
The geometrical properties (area, perimeter, major and minor axis) and morphometry features were computed. The lithogenic particles were characterized by grain size and morphometric descriptors: circularity index (CI) and roundness index (RI, Wadell 1934), 
which will be defined in the next section. The volume of the particles was calculated from their area (Okada et al. 2001). Particle volume was adjusted to an ellipsoid because it has been observed that an ellipsoidal volume is closer to the 3D shape of the mineral particles (Jaramillo et al. 2011). Ellipse axes were then calculated using their roundness and particle area, following the equations:

$$
\text { Major axis }=\sqrt{\frac{4 \cdot \text { Area }}{\pi \cdot \text { Roundness }}}
$$

Minor axis $=$ Major axis $\times$ Roundness

Particle volume $=\frac{4}{3} \pi \frac{\text { Major axis }}{2} \frac{\text { Minor axis }}{2} \frac{\text { Major axis }}{4}$

\section{Morphometry and mass}

The software calculated the CI and the RI. These parameters describe the geometrical complexity of the particles. The CI approximates the particle sphericity and was defined by Blott and Pye (2008) as

$$
\mathrm{CI}=\pi \frac{\text { Area }}{\text { Perimeter }^{2}}
$$

The RI approximates the particle irregularity and was determined as the ratio between the minor and the major dimensions of the particle. Again, an ellipse was chosen as the best representation, and major and minor dimensions correspond to the major axis and minor axis, which was equivalent to the particle area. The expression is given below, following Blott and Pye (2008):

$$
\mathrm{RI}=4 \frac{\text { Area }}{\pi \cdot{\text { Major } \text { axis }^{2}}^{2}}
$$

According to Jaramillo et al. (2016), the mean density of the lithogenic particles collected in the sediment trap, considering its mineralogical composition, was $3.4 \mathrm{mg} \mathrm{mm}^{-3}$. Particle mass was therefore estimated from their volume and density. The lithogenic flux (in $\left.\mathrm{mg} \mathrm{m}^{-2} 12 \mathrm{~h}^{-1}\right)$ was determined considering the trap area $\left(0.125 \mathrm{~m}^{2}\right)$ and the sampling time $(12 \mathrm{~h})$. The intermediate axis of the collected particles was used for the accumulated grain size distribution.

Biogenic particles were estimated using a similar procedure to those used in lithogenics. Due to their irregularity (chitin), as well as to the fact that many of them have hollow shells (foraminifers and gastropods), their volume was calculated from the surface area multiplied by an estimated mean height of 0.012 $\mathrm{mm}$ for foraminifera and gastropods (carbonates) and $0.005 \mathrm{~mm}$ for crustaceans (chitin). Their density values were $1370 \mathrm{~kg} \mathrm{~m}^{-3}$ for chitin (https://www.guidechem. com/dictionary/en/1398-61-4.html) and $2710 \mathrm{~kg} \mathrm{~m}^{-3}$ for carbonates (as calcite, http://webmineral.com/data/ Calcite.shtml\#.XCZ1Wlz7SyI). POC analysis was performed according to the procedures described by Ariza et al. (2015). Dissolved organic carbon adsorption onto the filters ranged from 0.3 to $1.6 \mu \mathrm{mol} \mathrm{C}$ per $25 \mathrm{~mm}$ diameter GF/F filter (less than $3.5 \%$ of the POC signal), similar to the blanks reported by Alonso-González et al. (2010a).

No opal individuals or fragments (radiolarian or diatoms) were identified by binocular study in these images, due to the scale (pixel definition was $2 \mathrm{~mm}$ ). A binocular study was used for particle geochemistry identification through SEM images with only four filters $(2 \mathrm{~d}, 2 \mathrm{n}, 4 \mathrm{~s}, 4 \mathrm{n})$ and only two diatoms or radiolarians were found. The abundance of silica biogenic particles has been determined in other studies (using the automated wet leaching method; Müller and Schneider, 1993 ) at this same area and depth, and also resulted in low values ( $0.21 \mathrm{mg} \mathrm{m}^{-2} \mathrm{day}^{-1}$, in Neuer et al. 2004).

The theoretical settling velocity (V) was calculated by the Stokes' law as follows (Allen 1992):

$$
\mathrm{V}=\frac{1}{18 \mu} d^{2} g\left(\rho_{s}-\rho_{f}\right)
$$

where $\rho_{s}$ is the quartz spheres density $\left(\rho_{s}=2650 \mathrm{~kg}\right.$ $\left.\mathrm{m}^{-3}\right), \rho_{f}$ is the seawater density $\left(\rho_{f}=1025 \mathrm{~kg} \mathrm{~m}^{-3}\right), \mu$ is the seawater viscosity $\left(9.05 \times 10^{-4} \mathrm{~N} \mathrm{~s} \mathrm{~m}^{-2}\right.$ at $\left.10^{\circ} \mathrm{C}\right), g$ is the standard acceleration due to gravity $(g=9.80665 \mathrm{~m}$ $\mathrm{s}^{-2}$ ), and $d$ is the particle diameter, in $\mathrm{mm}$.

\section{RESULTS}

Two grain size groups of lithogenic particles were identified (Fig. 4), one centred on finer particles, with a geometric mean of $22 \pm 3 \mathrm{~mm}$ (corresponding to samples $2 \mathrm{~d}, 2 \mathrm{n}, 7 \mathrm{~d}, 7 \mathrm{n}, 9 \mathrm{~d}, 10 \mathrm{~d}, 10 \mathrm{n}, 12 \mathrm{~d}$ and $12 \mathrm{n}$ ), and one on coarser particles, with a geometric mean of $57 \pm 16$ mm (4n, 3d, 3n, 5d, 5n, 8d, 8n, 11d and 11n). The average grain size of lithogenic particles was coarser as the lithogenic fluxes increased, except for 9d (Figs 4 and 5A). Particle sphericity (CI) was higher in the samples with larger grain size distributions and fluxes (Fig. 5B-C).

Chitin flux showed significant differences between diurnal and nocturnal periods, but the lithogenic, foraminifera and POC fluxes did not (t-test for paired lithogenic values and Wilcoxon test for the rest; significance levels, 0.286, 0.953, 0.027 and 0.910 for lithogenic,

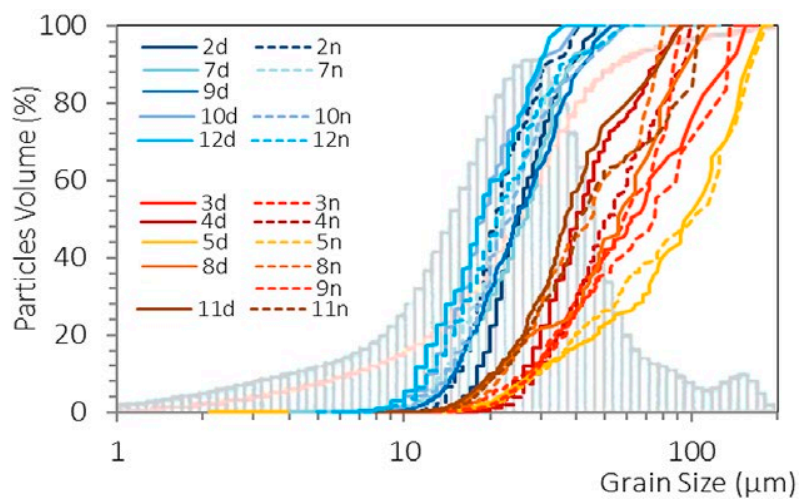

Fig. 4. - Grain size distributions of the lithogenic particles collected in this study. Numbers refer to the different days of April 2011, and the letters $\mathrm{d}$ and $\mathrm{n}$ indicate whether the sample corresponds to a diurnal or nocturnal period. The dashed line (pink) and the histogram correspond to modal and cumulative percentage volume curves for natural Saharan dust deposited on the island of Gran Canaria in the first week of March 2004 in Menéndez et al. (2009). Original dust analysis courtesy of Kenneth Pye. 
10 Mean gran size

100
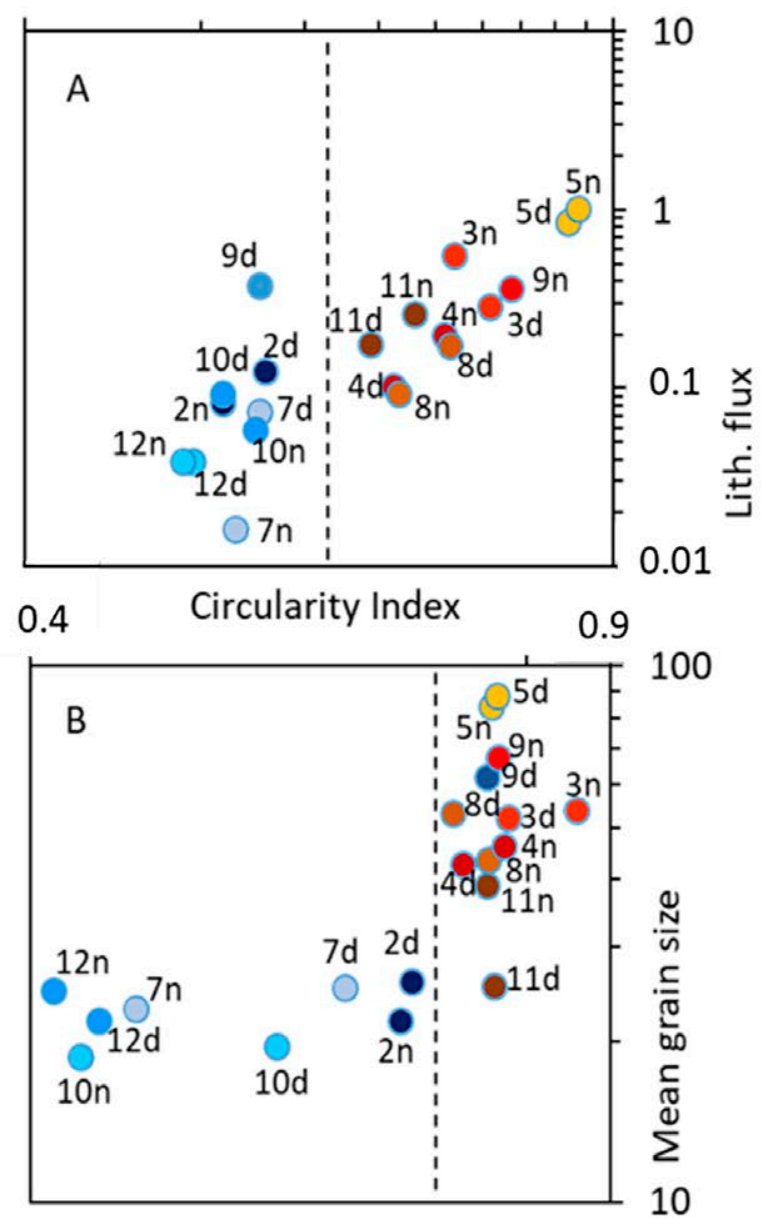

100

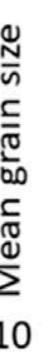

\section{$0.4 \quad$ Circularity Index $\quad 0.9$}

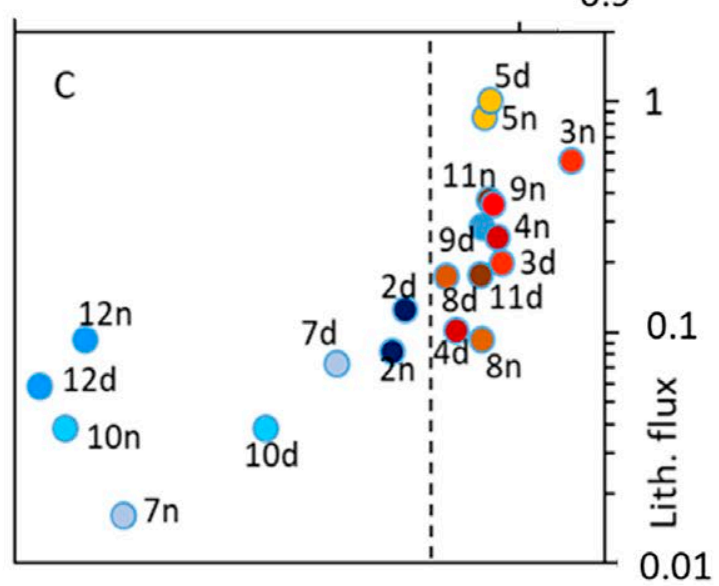

Fig. 5. - A, the relationship of mean grain size, in $\mathrm{mm}$, and the lithogenic flux, in $\mathrm{mg} \mathrm{m}^{-2} 12 \mathrm{~h}^{-1} ; \mathrm{B}$, the $\mathrm{CI}$ and the mean grain size, in $\mathrm{mm}$; and $\mathrm{C}$, the CI and the lithogenic flux, in $\mathrm{mg} \mathrm{m}^{-2} 12 \mathrm{~h}^{-1}$. Legend: the plot number is the day, $\mathrm{n}$ for night and $\mathrm{d}$ for day; the dot colours are the same as in Figures 3 and 4.

POC, chitin and foraminifers respectively; Fig. 6). Diurnal fluxes were about $81 \%$ lower than nocturnal ones for chitin fluxes. A positive and significant correlation was only observed for lithogenic and chitin fluxes (Fig. 7 ), suggesting that other fluxes were independent of the

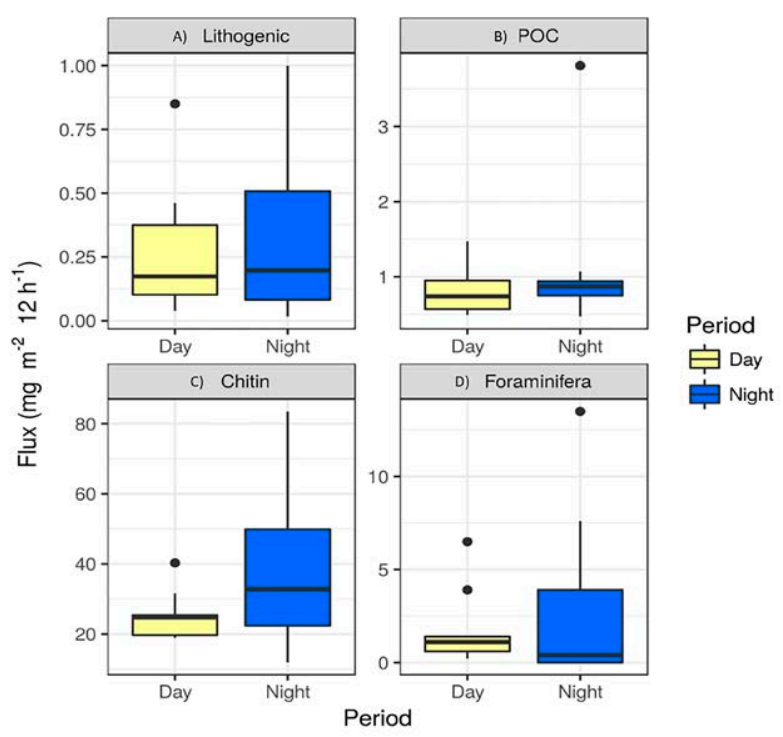

Fig. 6. - Box-plots of the diurnal and nocturnal periods from lithogenic flux (A), POC flux (B), chitin flux (C), and foraminifera flux (D). Chitin flux is the only one that shows significant differences between day and night fluxes. Further details in the text.

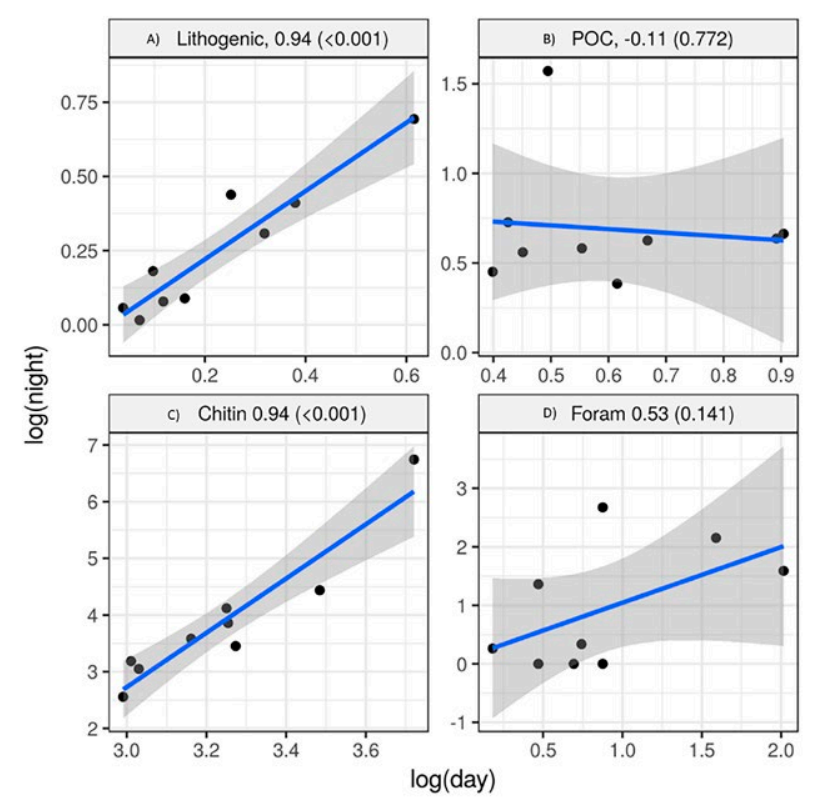

Fig. 7. - Diurnal and nocturnal correlations from lithogenic flux (A), POC flux (B), chitin flux (C) and foraminifera flux (D) with $r$ (p-value). Axes show the quantiles (percentiles) of each parameter. Further details in the text.

diurnal-nocturnal cycle. Independent behaviour would thus be reflected in the lack of association between the two parameters during the day or night.

The lithogenic mineral particles identified were illite, calcite, hematite, quartz, barite, and minor amounts of kaolinite (Fig. 8A-E). The mean biogenic material was composed mostly of chitin from crustacean exoskeletons, TEPs and carbonate (Fig. 8F-J). This latter component mainly originated from foraminifera, generally Globorotaria sp. Minor amounts of gastropods, coccolithophorid shells (coccoliths) and diatoms were 

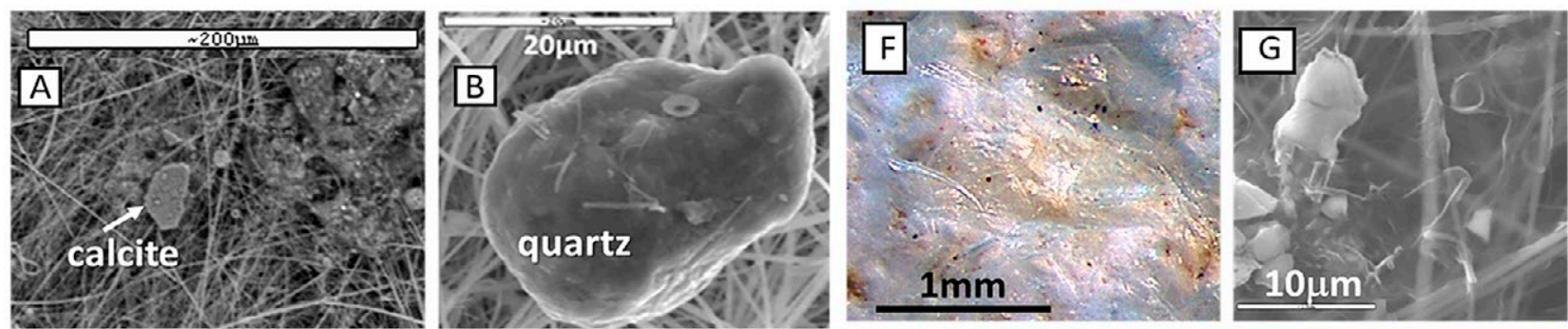
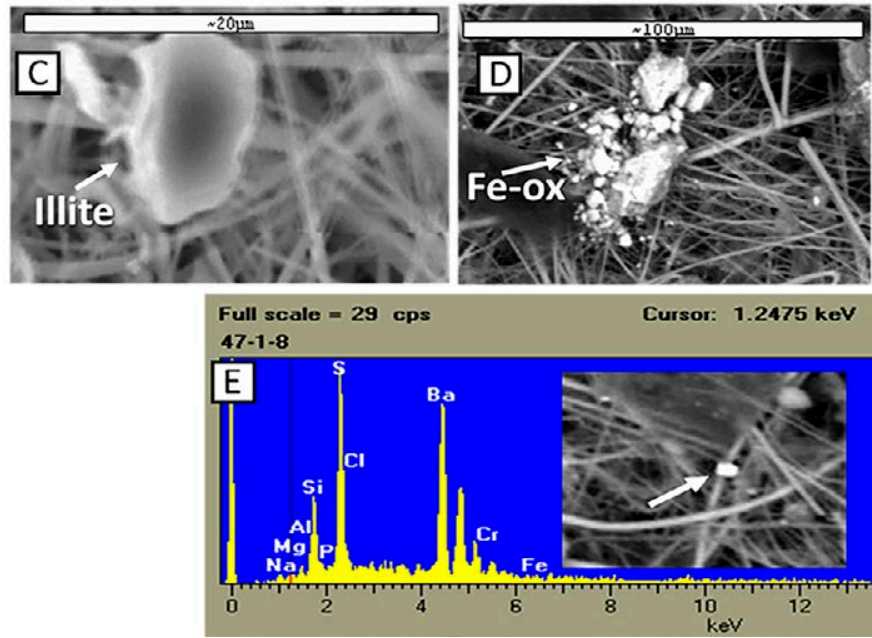
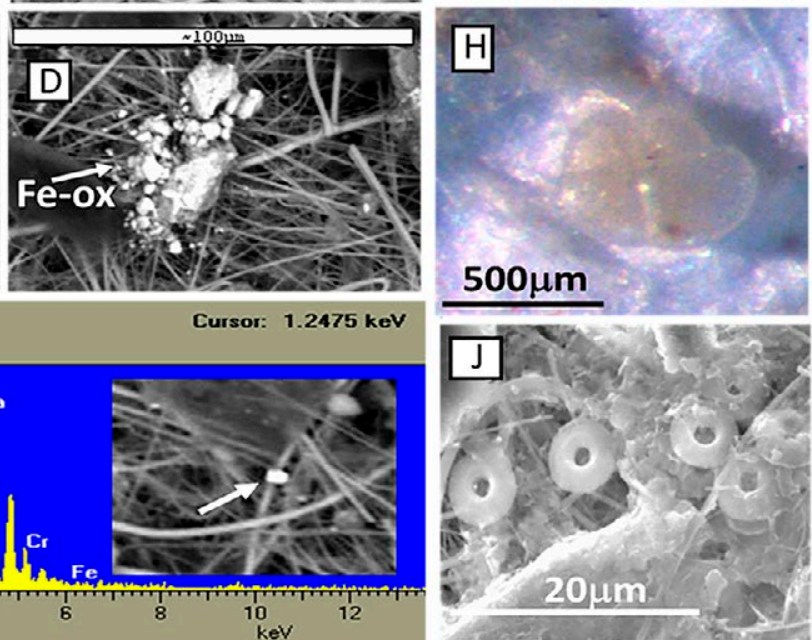
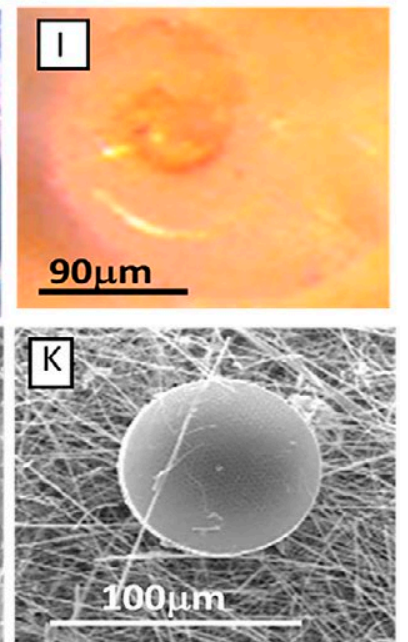

Fig. 8. - The main lithogenic mineral particles identified by SEM-EDX: A, calcite; B, quartz; C, illite; and D, hematite; E, image and spectrum analysis of a barite particle. The main biogenic material identified by binocular and SEM-EDX; F, chitin from crustaceans; G, TEP; H, foraminifer (Globorotaria hirsuta); I, gastropod; J, coccolithophorid platings (coccoliths); K, diatom individual.
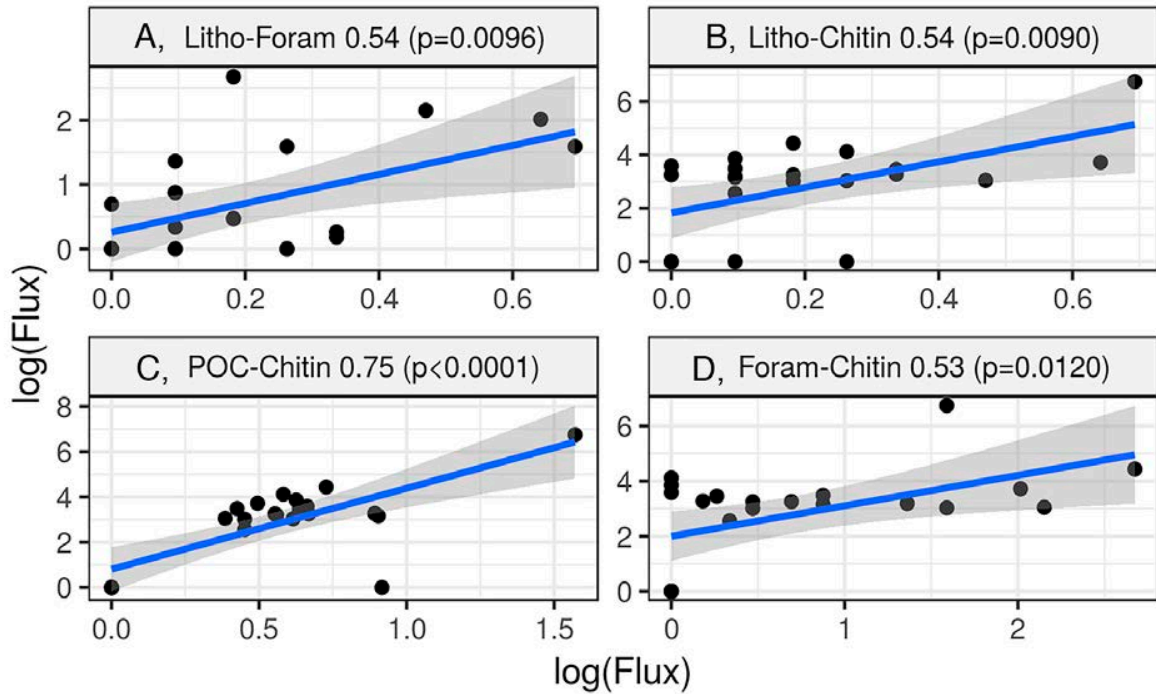

Fig. 9. - The significant linear adjustments, with $r$ (p-value), between fluxes: A, lithogenic (Y-axe) vs foraminifer (X-axe); B, lithogenic (Y-axe) vs chitin (X-axe); C, POC (Y-axe) vs chitin (X-axe); D, foraminifer (Y-axe) vs chitin (X-axe). Units in all axes are expressed in $\mathrm{mg} \mathrm{m}^{-2} 12 \mathrm{~h}^{-1}$.

also identified (Fig. 8F). No corrosion or dissolution was observed in the coccoliths or the diatom cells.

The mean lithogenic flux $\left(0.8 \pm 0.6 \mathrm{mg} \mathrm{m}^{-2}\right.$ day $\left.^{-1}\right)$ was about one order of magnitude lower than the Saharan dust flux $\left(5 \pm 4 \mathrm{mg} \mathrm{m}^{-2} \mathrm{day}^{-1}\right)$. The biogenic carbonate and chitin fluxes were $6.0 \pm 7.4$ and $154 \pm 386$ $\mathrm{mg} \mathrm{m}{ }^{-2}$ day $^{-1}$, respectively (Fig. 3). The Saharan dust event took place between 31 March and 2 April, with the highest values of dust flux during the latter date. The atmosphere was completely clean of dust from 3 to 9 April, when a new dust input began (Figs 2 and 3). The maximum peak of foraminifera was observed on 4 April, while the highest values of POC, chitin and lithogenic fluxes were observed on 5 April. There was a delay of about three days between the peak of dust flux, measured on 2 April, and the lithogenic, chitin and POC fluxes detected on 5 April. On a daily basis, Saharan dust and lithogenic fluxes showed no correlation, though the correlation improved, but not significantly $(r=0.41)$, taking into account the three-day 
delay between the lithogenic and Saharan dust fluxes. Significant correlations were then established between lithogenic and foraminifer fluxes, lithogenic and chitin fluxes, POC and chitin fluxes and foraminifer and chitin fluxes (Fig. 9).

The calculated gravimetric settling rate of the lithogenic particles linked to the Saharan dust events was $150 \mathrm{~m}$ for 3 days $\left(\mathrm{v}=50 \mathrm{~m} \mathrm{day}^{-1}\right)$. Considering the average grain size for the lithogenic flux associated with the Saharan plume dust, the theoretical settling velocity following Stokes' law was $v_{\text {Stokes }}=275 \mathrm{~m} \mathrm{day}^{-1}$, meaning that these particles would reach the trap at $150 \mathrm{~m}$ depth in only 0.5 days. The measured settling velocity was thus nearly six-fold lower than the theoretical one.

\section{DISCUSSION}

\section{Grain size and dragging effect}

A typical Saharan dust event has an average grain size distribution of $30 \pm 19 \mathrm{~mm}$ (dashed line [pink] distribution in Figure 4) (Menéndez et al. 2009), but the size distribution observed at $150 \mathrm{~m}$ depth in this study after a dust event was significantly coarser (average grain size of $57 \pm 16 \mathrm{~mm}$ ). This mismatch could be due to differences in the sinking rate between large and small particles, as was also observed in mesocosm experiments for particles larger and smaller than $5 \mathrm{~mm}$ (Bressac et al. 2014). Smaller particles could be retained in the water column because of their low weight and density, while larger ones could sink at higher velocities. Biological activity could also retain small particles in the upper layers as an effect of ingestion by micro- and mesozooplankton (see Jaramillo et al. 2016). The aggregation effect of the organic matter (Jackson et al. 2015) and the formation of sticky TEPs, more stable in oxidation processes than the organic matter (Pakulski and Benner 1994), could also contribute to the presence of larger particles in the sediment trap. These TEPs were observed in the filters because of their relatively good preservation after the procedure described to eliminate the organic matter. The oceanic deposition of a Saharan dust event in surface waters produces an increment of lithogenic particles, favouring an intensification of the POC and TEP ballast effect (Mari et al. 2017). These TEPs are a key factor in the formation of new aggregates, which could be unspoiled during the settling process through the mixed layer, and consequently accelerate the sinking velocity of the POC (Reid et al. 2003, Neuer et al. 2004, de Leeuw et al. 2014)

Lithogenic particles are denser, and act as ballast, supporting the vertical transport of biogenic aggregates to the deep ocean (Armstrong et al. 2002). These particles could be incorporated into organic aggregates, acting as ballast increasing sinking, and enhancing the carbon exported to the mesopelagic zone (see van der Jagt et al. 2018). Conversely, these dragging processes force a reduction in the sinking velocities of the lithogenic particles. In this sense, we observed a sixfold reduction in the vertical velocity compared with the theoretical Stokes settling velocities $\left(50 \mathrm{~m} \mathrm{day}^{-1}\right.$ instead of $275 \mathrm{~m} \mathrm{day}^{-1}$ ). Physical processes in the water column, such as mixing and turbulence, could also promote a slowdown of sinking particles, but the $\mathrm{Ca}$ nary Current velocity (about $4300 \mathrm{~m} \mathrm{day}^{-1}$; Sangrà et al. 2009) could be neglected in the settling calculations due to the free-drifting line design of this sediment trap. Maximum vertical velocities in this area of the ocean were estimated in oceanic eddies. The vertical upward velocity generated by cyclonic eddies shed by Gran Canaria Island was $\mathrm{w}=7.5 \mathrm{~m} \mathrm{day}^{-1}$ (Barton et al. 1998), though this value might represent a slight reduction of about $3 \%$ in the sinking velocity of lithogenic particles.

\section{Settling rates}

The three-day delay between the lithogenic flux and the dust peaks was taken into account to calculate the settling particles rate from the ocean surface to $150 \mathrm{~m}$ depth, yielding a value of $50 \mathrm{~m} \mathrm{day}^{-1}$. This value is equal to that observed by Jackson et al. (2015) in the upper $100 \mathrm{~m}$ of the ocean along the southwest coast of the United States and in the range of the maximum velocities registered in a mesocosms experiment at 15 $\mathrm{m}$ depth in Corsica, of about 24 to $86 \mathrm{~m} \mathrm{day}^{-1}$, corresponding to organic-mineral aggregate populations (>61.2 $\mu \mathrm{m}$; Bressac et al. 2012). A settling estimation rate was also made close to Cape Verde at 1000-2500 $\mathrm{m}$ depth, resulting in this case of $150 \mathrm{~m} \mathrm{day}^{-1}$ (Bory and Newton 2000). This value is thus three times the velocity observed in our study. Berelson (2002) obtained an increase of the settling rate by a factor of two- to ten-fold between 100 and $2000 \mathrm{~m}$ depth, which was explained due to the formation of aggregates. Our values for the epipelagic zone could thus be reasonable, since the formation of aggregates should be lower in upper layers than aggregation during their long downward sinking, entering the meso- and bathypelagic zones. Both lithogenic and biogenic fluxes seem to increase with depth (Table 1). This intensification of fluxes with depth can also be explained as lateral advection (Alonso-González et al. 2010b, Freudenthal et al. 2001, Sprengel et al. 2002). However, lithogenic fluxes at similar depths also show significant changes depending on local conditions and factors such as trophic status, continental sediment supply, seasonality, upwelling and/or ocean currents. Recent efforts to standardize lithogenic flux methods demonstrated a discrepancy of more than one order of magnitude in these values (Anderson et al. 2016).

The coincidence of peaks in biogenic (POC and chitin) and lithogenic fluxes (Fig. 4) suggests a similar settling velocity of these particles, probably due to the aggregation effect of the stable TEPs. Accordingly, the observed quantitative relationship between dust and lithogenic, chitin and foraminifer fluxes (Fig. 9) might reflect their ballast-balance interaction. The highest sinking rates of the marine snow were observed in dust-rich ocean regions off NW Africa, but could not be explained by carbonate content (Fischer and Karakas 2009). Lithogenic particles (of Saharan dust origin) may play a considerable role in the POC-TEP-carbonate biogenic aggregate fluxes, as observed in the 
Table 1. - Recompilation of lithogenic and biogenic fluxes from a selection of pelagic campaigns.

\begin{tabular}{|c|c|c|c|c|c|c|c|c|}
\hline \multirow{2}{*}{ Study Area } & \multirow{2}{*}{ References } & \multirow{2}{*}{ Depth (m) } & \multicolumn{4}{|c|}{ Fluxes $\left(\mathrm{mg} \mathrm{m}^{-2}\right.$ day $\left.^{-1}\right)$} & \multirow{2}{*}{$\begin{array}{c}\text { Litho/ } \\
\text { (Litho+Bio) }\end{array}$} & \multirow{2}{*}{$\begin{array}{c}\text { Litho/ } \\
\text { (Litho+Dust) }\end{array}$} \\
\hline & & & Litho & Biog & opal & carbonate & & \\
\hline Japan Sea & Otosaka et al. 2004 & $\begin{array}{c}927 \\
996 \\
1057 \\
1131 \\
2100 \\
2746 \\
3043 \\
3065\end{array}$ & $\begin{array}{c}119 \\
46 \\
38 \\
106 \\
91 \\
74 \\
33 \\
50\end{array}$ & $\begin{array}{l}- \\
- \\
- \\
- \\
- \\
- \\
- \\
-\end{array}$ & $\begin{array}{l}- \\
- \\
- \\
- \\
- \\
- \\
- \\
-\end{array}$ & $\begin{array}{c}321 \\
103 \\
68 \\
146 \\
160 \\
146 \\
65 \\
64\end{array}$ & $\begin{array}{l}0.3 \\
0.3 \\
0.4 \\
0.4 \\
0.4 \\
0.3 \\
0.3 \\
0.4\end{array}$ & $\begin{array}{l}- \\
- \\
- \\
- \\
- \\
- \\
- \\
-\end{array}$ \\
\hline Panama Basin & Honjo et al. 1982 & $\begin{array}{c}667 \\
1268 \\
2265 \\
2869 \\
3769\end{array}$ & $\begin{array}{l}11 \\
14 \\
24 \\
32 \\
50\end{array}$ & $\begin{array}{c}103 \\
91 \\
104 \\
126 \\
129\end{array}$ & $\begin{array}{l}- \\
- \\
- \\
-\end{array}$ & $\begin{array}{l}- \\
- \\
- \\
- \\
-\end{array}$ & $\begin{array}{l}0.1 \\
0.1 \\
0.2 \\
0.2 \\
0.3\end{array}$ & $\begin{array}{l}- \\
- \\
- \\
-\end{array}$ \\
\hline NW Pacific & Maeda et al. 2007 & $\begin{array}{c}0 \text { (Asian dust) } \\
770 \\
5100\end{array}$ & $\begin{array}{c}8 \\
12 \\
20\end{array}$ & $\begin{array}{l}- \\
- \\
-\end{array}$ & $\begin{array}{l}- \\
66 \\
67\end{array}$ & $\begin{array}{l}- \\
- \\
-\end{array}$ & $\begin{array}{l}- \\
0.2 \\
0.3\end{array}$ & $\begin{array}{c}0.6 \\
-\end{array}$ \\
\hline West Madeira & Brust and Waniek, 2010 & 2000 & $5-17$ & 64 & - & - & $0.1-0.2$ & - \\
\hline Canary Islands & Ratmeyer et al. 1999 & $\begin{array}{l}1000 \\
3000\end{array}$ & $\begin{array}{l}11 \\
21\end{array}$ & $\begin{array}{l}- \\
-\end{array}$ & - & - & - & $\begin{array}{l}- \\
-\end{array}$ \\
\hline Cape Blanc, Saharan & Ratmeyer et al. 1999 & $\begin{array}{c}700 \\
3500\end{array}$ & $\begin{array}{l}31 \\
56\end{array}$ & $\begin{array}{l}- \\
-\end{array}$ & $\begin{array}{l}- \\
-\end{array}$ & $\begin{array}{l}- \\
-\end{array}$ & $\begin{array}{l}- \\
-\end{array}$ & $\begin{array}{l}- \\
-\end{array}$ \\
\hline Cape Verde Islands & Ratmeyer et al. 1999 & $\begin{array}{l}1000 \\
4500\end{array}$ & $\begin{array}{l}62 \\
28\end{array}$ & - & $\begin{array}{l}- \\
-\end{array}$ & - & - & $\begin{array}{l}- \\
-\end{array}$ \\
\hline $\begin{array}{l}\text { off W Cape Verde } \\
\text { oligotrophic site }\end{array}$ & & $\begin{array}{l}1000 \\
2500\end{array}$ & $\begin{array}{c}9 \\
10\end{array}$ & - & - & $\begin{array}{l}21 \\
21\end{array}$ & $\begin{array}{l}0.3 \\
0.3\end{array}$ & $\begin{array}{l}- \\
-\end{array}$ \\
\hline $\begin{array}{l}\text { off NE Cape Verde } \\
\text { mesotrophic site }\end{array}$ & Bori and Newton, 2000 & $\begin{array}{l}\sim 1100 \\
\sim 2200 \\
\sim 3200\end{array}$ & $\begin{array}{l}57 \\
66 \\
74\end{array}$ & $\begin{array}{l}- \\
- \\
-\end{array}$ & $\begin{array}{l}24 \\
16 \\
13\end{array}$ & $\begin{array}{l}121 \\
122 \\
105\end{array}$ & $\begin{array}{l}0.3 \\
0.3 \\
0.4\end{array}$ & $\begin{array}{l}- \\
- \\
-\end{array}$ \\
\hline $\begin{array}{l}\text { ESTOC, late winter- } \\
\text { spring }\end{array}$ & Neuer et al. 1997 & $\begin{array}{l}1000 \\
3000\end{array}$ & $\begin{array}{l}43 \\
50\end{array}$ & $\begin{array}{l}90 \\
84\end{array}$ & $\begin{array}{c}10 \\
6\end{array}$ & $\begin{array}{l}80 \\
77\end{array}$ & $\begin{array}{l}0.3 \\
0.4\end{array}$ & $\begin{array}{l}- \\
-\end{array}$ \\
\hline \multirow[t]{2}{*}{ ESTOC, spring } & Neuer et al. 2002 & $\begin{array}{c}500 \\
750 \\
3000\end{array}$ & $\begin{array}{l}- \\
- \\
-\end{array}$ & $\begin{array}{l}- \\
- \\
-\end{array}$ & $\begin{array}{l}- \\
- \\
-\end{array}$ & $\begin{array}{l}- \\
- \\
-\end{array}$ & $\begin{array}{l}0.1 \\
0.3 \\
0.3\end{array}$ & $\begin{array}{l}- \\
- \\
-\end{array}$ \\
\hline & Neuer et al. 2004 & $\begin{array}{l}0 \text { (Sah. dust) } \\
330-640\end{array}$ & $\begin{array}{l}21 \\
3.2\end{array}$ & 5.5 & $0 . \overline{21}$ & 5.3 & 0.4 & - \\
\hline Canary Basin & present work & $\begin{array}{c}0 \text { (Sah. dust) } \\
150\end{array}$ & $\begin{array}{l}5.0 \\
0.8\end{array}$ & - & - & - & - & - \\
\hline
\end{tabular}

present study. Coupled with the occurrence of lithogenic-biogenic fluxes, this finding could contribute to more accurate prediction in ocean carbon pump models.

\section{Diurnal/nocturnal fluxes}

The lithogenic, POC and foraminifera fluxes did not seem to vary between day and night. Lithogenic flux was regular in time, but POC and foraminifera fluxes appeared to be more irregular. Conversely, the chitin flux was larger at night, the greatest difference being with the largest flux (Fig. 6). Despite the extraordinary amount of chitin produced annually in the oceans (Souza et al. 2011), few studies about the chitin flux can be found in the literature. Montgomery et al. (1990) study the chitin flux measured in the mixed layer of the subarctic Pacific study (4.4-1.3 $\mathrm{mg} \mathrm{m}^{-2}$ day $\left.^{-1}\right)$, much lower than that measured in the Canary Basin.

Ariza et al. (2015) observed large zooplankton ( $>1$ $\mathrm{mm})$ to show a clear day/night difference of biomass $(\mathrm{D} / \mathrm{N}=0.63 \pm 0.19)$ in the epipelagic layer as a consequence of the diel vertical migration of copepods, euphausiids and chaetognaths. This is a $59 \%$ increase in the biomass of large organisms in the upper layers of the ocean at night, and a quite significant increase in crustacean density passing the depth of the sediment trap every night. The explanation for this increase of chitin at night must be related to the vertical migration of zooplankton. We removed large swimmers (see material and methods) but not smaller sizes; however, we observed small chitin pieces of these crustaceans, probably pieces that were broken when crustaceans were eaten through trophic interaction at night. The origin of these small pieces of chitin in the sediment trap remains unknown, but further research should be undertaken to ascertain their role as a flux or, simply, as contamination.

\section{Fluxes and their interrelationships}

The Saharan dust plume in early April 2011 produced an increase of one and two orders of magnitude in the lithogenic and chitin fluxes, respectively. Rather than biogenic production, the considerable flux increase could be due to mineral particles promoting organic-inorganic aggregation, increasing the sinking velocity of these aggregates and providing physical protection against the remineralization of the labile organic matter component (van der Jagt et al. 2018). The 
measured magnitudes of particle fluxes at $150 \mathrm{~m}$ depth in the Canary Current mixed layer (Table 1) were not balanced, the chitin flux clearly predominating $(96 \%)$ over far smaller foraminifer-carbonate (3\%) and lithogenic $(0.3 \%)$ fluxes. Neuer et al. (2004) also showed that the carbonate biogenic flux was in the same range of values as those observed in the present study; the lithogenic flux was lower in the present study (Table 1), but the lithogenic/(lithogenics+dust) ratio was similar in the two studies (0.1). This finding suggests that in this oceanic region, as expected, the inputs of lithogenic fluxes are restricted to Saharan dust, without any significant effect from fluvial input. According to the data presented by Maeda et al (2007), the ratio for the NW Pacific Ocean was higher (0.6; Table 1), due to the important fluvial contribution to the lithogenic flux in this area.

Opal fluxes (diatoms and radiolarian) were not detected by our image processing but the values measured by Neuer et al. (2004) in this area and at this depth were low $\left(0.21 \mathrm{mg} \mathrm{m}^{-2} \mathrm{day}^{-1}\right)$. It seems that diatoms tend to sink rapidly to the seafloor as large chains (Berelson 2002), and therefore might not contribute to marine snow formation. Calcium carbonate organisms are therefore the predominant biogenic flux collected in sediment traps in the Canary region (Fischer et al. 1996, Abrantes et al. 2002, Alonso-González et al. 2010a) and also further south (Korte et al. 2016).

The low export of biogenic matter characteristic of the Canary Basin waters due to their oligotrophy (Neuer et al. 2004) could also accelerate export because of the link to the lithogenic fluxes. POC flux north of the Canary Archipelago was on average 4.5 $\pm 2.9 \mathrm{mgC}$ $\mathrm{m}^{-2}$ day $^{-1}$ at $200 \mathrm{~m}$ depth (Helmke et al. 2010), while Ariza et al. (2015) found a value of $11.9 \pm 5.8 \mathrm{mgC} \mathrm{m}^{-2}$ day $^{-1}$ at $150 \mathrm{~m}$ depth after the late winter bloom in these waters. These slightly higher values were due, in part, to the larger value observed three days after the dust deposition. As stated above, lithogenic material can be incorporated into organic aggregates, acting as ballast, increasing sinking, and enhancing the carbon exported to the mesopelagic zone (van der Jagt et al. 2018).

Finally, a comparison of lithogenic and biogenic fluxes in other regions, at similar sampling depths, such as in the Panama Basin (Honjo et al. 1982) and the NW Pacific (Maeda et al. 2007), showed much higher values (11 and $12 \mathrm{mg} \mathrm{m}^{-2}$ day $^{-1}$, respectively) than those observed here in the Canary Basin, but the lithogenic/ (lithogenics+biogenic) ratio was similar to that of these studies $(0.1-0.4)$. This generally small range could be a consequence of the well-known micronutrient effect (i.e. iron) of the lithogenic minerals (Jickells et al. 2005, Hernández-León et al. 2007, Álvarez-Salgado and Arístegui 2015), controlling biological production in relation to micronutrient availability. Bressac et al. (2014) did not find significant correlations between primary production and the POC flux in the framework of dust seeding mesocosm experiments, and thus showed that POC flux was instead explained by dust seeding, estimating that $42 \%$ to $50 \%$ of POC fluxes were associated strictly through processes of aggregation, and most probably sorption, of the lithogenic particles.

\section{CONCLUDING REMARKS}

We found that particle size distribution at $150 \mathrm{~m}$ depth corresponding to dust events in the Canary Basin was on average 2.5 times coarser (average grain size of $57 \pm 16 \mathrm{~mm}$ during the dust event versus $22 \pm 3$ $\mathrm{mm}$ during non-dust periods). Few studies account for these fluxes using free-drifting sediment traps in the mixed layer where major biological processes in the water column take place. The lithogenic and biogenic carbonate fluxes detected at $150 \mathrm{~m}$ depth in the Canary Basin were $0.8 \pm 0.6$ and $6.0 \pm 7.4 \mathrm{mg} \mathrm{m}^{-2}$ day $^{-1}$, respectively. The peaks of Saharan dust flux input in the ocean were followed by lithogenic and biogenic flux maxima with a delay of about three days, indicating a settling rate of about $50 \mathrm{~m}$ day $^{-1}$, nearly six times lower than the predicted velocity for these particles $\left(v_{\text {Stokes }}=275 \mathrm{~m} \mathrm{~d}^{-1}\right)$. The possible ballast activity of the lithogenic particles, dragging TEPs and POC, and the coincidence of biogenic and lithogenic fluxes could explain this slowdown in lithogenic fluxes.

\section{ACKNOWLEDGEMENTS}

This work was financed by the research projects Lunar Cycles and Iron Fertilization (Lucifer, CTM200803538), Migrants and Active Flux in the Atlantic Ocean (Mafia, CTM2012-39587) and Biomass and Active Flux in the Bathypelagic Zone (Bathypelagic, CTM2016-78853-R) funded by the Ministry of Economy and Competitiveness of the Spanish Government.

This article is a publication of the Instituto Oceanografía y Cambio Global (IOCAG, ULPGC) and of the Unidad Océano y Clima of the Universidad de Las Palmas de Gran Canaria, a CSIC R\&D associate unit.

\section{REFERENCES}

Abrantes F., Meggers H., Nave S., et al. 2002. Fluxes of microorganisms along a productivity gradient in the Canary Islands region $\left(29^{\circ} \mathrm{N}\right)$ : implications for paleoreconstructions. Deep-Sea Res. II 49: 3599-3629. https://doi.org/10.1016/S0967-0645(02)00100-5

Alldredge A.L., Silver M.W. 1988. Characteristics, dynamics and significance of marine snow. Prog. Oceanogr. 20: 41-82. https://doi.org/10.1016/0079-6611(88)90053-5

Alldredge A.L., Passow U., Logan B.E. 1993. The abundance and significance of large, transparent organic particles in the ocean. Deep-Sea Res. I 40: 1131-1140. https://doi.org/10.1016/0967-0637(93)90129-Q

Allen J.R.L. 1992. Principles of physical sedimentology. The Blackburn Press; Chapman \& Hall, New Jersey, 272 pp.

Alonso-González I.J., Arístegui J., Lee C., et al. 2010a. Regional and temporal variability of sinking organic matter in the subtropical northeast Atlantic Ocean: a biomarker diagnosis. Biogeosciences 7: 2101-2115. https://doi.org/10.5194/bg-7-2101-2010

Alonso-González I.J., Arístegui J., Lee C, et al. 2010b. Role of slowly settling particles in the ocean carbon cycle. Geophys. Res. Lett. 37. https://doi.org/10.1029/2010GL043827

Álvarez-Salgado X.A., Arístegui J. 2015. Organic matter dynamics in the Canary Current. In: Valdés L., Déniz-González I. (eds), Oceanographic and biological features in the Canary Current Large Marine Ecosystem. IOC Tech. Ser. 115: 151-159. IOCUNESCO, Paris. http://hdl.handle.net/1834/9185.

Anabalón V., Arístegui J., Morales C.E., et al. 2014. The structure of planktonic communities under variable coastal upwelling 
conditions off Cape Ghir $\left(31^{\circ} \mathrm{N}\right)$ in the Canary Current System (NW Africa). Prog. Oceanogr. 120: 320-339. https://doi.org/10.1016/j.pocean.2013.10.015

Anderson R.F., Cheng H., Edwards R.L., et al. 2016. How well do we quantify dust deposition to the ocean? Philos. Trans. R. Soc. A. 374: 20150285. https://doi.org/10.1098/rsta.2015.0285

Ansmann A., Tesche M., Althausen D., et al. 2008. Influence of Saharan dust on cloud glaciation in southern Morocco during SAMUM. J. Geophys. Res. 113: D04210. https://doi.org/10.1029/2007JD008785

Armstrong R.A., Lee C., Hedges J.I., et al. 2002. A new, mechanistic model for organic carbon fluxes in the ocean: based on the quantitative association of POC with ballast minerals. Deep-Sea Res. II 49: 219-236. https://doi.org/10.1016/S0967-0645(01)00101-1

Ariza A.V., Garijo J.C., Landeira J.M., et al. 2015. Migrant biomass and respiratory carbon flux by zooplankton and micronekton in the north east Atlantic Ocean (Canary Islands). Prog. Oceanogr. 134: $330-342$ http://doi.org/10.1016/j.pocean.2015.03.003

Astitha M., Kallos G., Spyrou C., et al. 2010. Modelling the chemically aged and mixed aerosols over the eastern central Atlantic Ocean potential impacts. Atmos. Chem. Phys. 10: 5797-5822. https://doi.org/10.5194/acp-10-5797-2010

Barton E.D., Arístegui J., Tett P., et al. 1998. The transition zone of the Canary Current upwelling region. Prog. Oceanogr. 41: 455-504. https://doi.org/10.1016/S0079-6611(98)00023-8

Basart S., Pérez C., Nickovic S., et al. 2012. Development and evaluation of the BSC-DREAM8b dust regional model over Northern Africa, the Mediterranean and the Middle East. Tellus B 64: 1-23. https://doi.org/10.3402/tellusb.v64i0.18539

Bauerfeind E., von Bodungen B. 2006. Underestimation of biogenic silicon flux due to dissolution in sediment trap samples. Mar. Geol. 226: 297-306. https://doi.org/10.1016/j.margeo.2005.11.001

Berelson W.M. 2002. Particle settling rates increase with depth in the ocean. Deep-Sea Res. II 49: 237-251. https://doi.org/10.1016/S0967-0645(01)00102-3

Blott S.J., Pye K. 2008. Particle shape: a review and new methods of characterization and classification. Sedimentology 55:31-63.

Bory A.J.-M., Newton P.P. 2000. Transport of airborne lithogenic material down through the water column in two contrasting regions of the eastern subtropical North Atlantic Ocean. Global Biogeochem. Cycles 14: 297-315. https://doi.org/10.1029/1999GB900098

Bressac M., Guieu C., Doxaran D., et al. 2012. A mesocosm experiment coupled with optical measurements to assess the fate and sinking of atmospheric particles in clear oligotrophic waters, Geo-Mar. Lett. 32: 153-164. https://doi.org/10.1007/s00367-011-0269-4

Bressac M., Guieu C., Doxaran D., et al. 2014. Quantification of the lithogenic carbon pump following a simulated dust-deposition event in large mesocosms, Biogeosciences 11: 1007-1020. https://doi.org/10.5194/bg-11-1007-2014

Brust J., Waniek J.J. 2010. Atmospheric dust contribution to deepsea particle fluxes in the subtropical Northeast Atlantic. DeepSea Res. I 57: 988-998. https://doi.org/10.1016/j.dsr.2010.04.011

Buesseler K.O., Antia A.N., Chen M., et al. 2007. An assessment of the use of sediment traps for estimating upper ocean particle fluxes. J. Mar. Res. 65: 345-416. https://doi.org/10.1357/002224007781567621

De Leeuw G., Guieu C., Arneth A., et al. 2014. Ocean-Atmosphere Interactions of Particles. In: Liss P.S., Johnson M.T. (eds), Ocean-Atmosphere Interactions of Gases and Particles, Springer, pp. 171-246.

Dong H.-P., Wang D.-Z., Dai M., et al. 2010. Characterization of particulate organic matter in the water column of the South China Sea using a shotgun proteomic approach. Limnol. Oceanogr. 55: $1565-1578$ https://doi.org/10.4319/10.2010.55.4.1565

Engelbrecht J.P., Menendez I., Derbyshire E. 2014. Sources of PM2.5 impacting on Gran Canaria, Spain. Catena 117: 119-132. https://doi.org/10.1016/j.catena.2013.06.017

Elder L.E., Hsiang A.Y., Nelson K., et al. 2018. Data Descriptor: Sixty-one thousand recent planktonic foraminifera from the Atlantic Ocean. Sci. Data 5: 180109. https://doi.org/10.1038/sdata.2018.109

Fischer G., Karakas G. 2009. Sinking rates and ballast composition of particles in the Atlantic Ocean: Implications for the organic carbon fluxes to the deep ocean. Biogeosciences 6: 85-102. https://doi.org/10.5194/bg-6-85-2009

Fischer G., Neuer S., Wefe G., et al. 1996. Short-term sedimentation pulses recorded with a fluorescence sensor and sediment traps at $900 \mathrm{~m}$ depth in the Canary basin, Limnol. Oceanogr. 41: 1354-1359. https://doi.org/10.4319/1o.1996.41.6.135

Freudenthal T., Neuer S., Meggers H., et al. 2001. Influence of lateral particle advection and organic matter degradation on sediment accumulation and stable nitrogen isotope ratios along a productivity gradient in the Canary Islands region. Mar. Geol. 177: 93-109. https://doi.org/10.1016/S0025-3227(01)00126-8

Haustein K., Pérez C., Baldasano J.M., et al. 2012. Atmospheric dust modelling from meso to global scales with the online NMMB/BSC-Dust model-Part 2: Experimental campaigns in Northern Africa. Atmos. Chem. Phys. 12: 2933-2958. https://doi.org/10.5194/acp-12-2933-2012

Helmke P., Neuer S., Lomas M.W., et al. 2010. Cross-basin differences in particulate organic carbon export and flux attenuation in the subtropical North Atlantic gyre. Deep-Sea Res. I 57: 213-227 https://doi.org/10.1016/j.dsr.2009.11.001

Hernández-León S., Almeida C., Bécognée P., et al. 2004. Zooplankton biomass and indices of grazing and metabolism during a late winter bloom in subtropical waters. Mar. Biol. 145: 1191-1200. https://doi.org/10.1007/s00227-004-1396-5

Hernández-León S., Gómez M., Arístegui J. 2007. Mesozooplankton in the Canary Current System: The coastal-ocean transition zone. Prog. Oceanogr. 74: 397-421. https://doi.org/10.1016/j.pocean.2007.04.010

Herrera I., López-Cancio J., Yebra L., et al. 2017. The effect of a strong warm winter on subtropical zooplankton biomass and metabolism. J. Mar. Res. 75: 557-577. https://doi.org/10.1357/002224017822109523

Honjo S., Spencer D.W., Farrington J.W. 1982. Deep Advective Transport of Lithogenic particles in Panama Basin. Science 216: $516-518$ https://doi.org/10.1126/science.216.4545.516

Huskin I., Viesca L., Anadón R. 2004. Particle flux in the Subtropical Atlantic near the Azores: influence of mesozooplankton. J. Plankton Res. 26: 403-415. https://doi.org/10.1093/plankt/fbh03

Jackson G.A., Checkley D.M., Dagg M. 2015. Settling of particles in the upper $100 \mathrm{~m}$ of the ocean detected with autonomous profiling floats off California. Deep-Sea Res. I 99: 75-86. https://doi.org/10.1016/j.dsr.2015.02.001

Jaramillo A., Menéndez I., Alonso I., et al. 2011. Textural and mineralogical characterization of terrigenous material from atmospheric inputs in the Canary basin. Published as a master thesis, Universidad de Las Palmas de Gran Canaria, 31 pp.

Jaramillo A., Menéndez I., Alonso I., et al. 2016. Grainsize, morphometry and mineralogy of airborne input in the Canary basin: evidence of iron particle retention in the mixed layer. Sci. Mar. 80: 395-408.

Jickells T.D., An Z.S., Andersen K.K., et al. 2005. Global iron connections between desert dust, ocean biochemistry, and climate. Science 308: 67-71. https://doi.org/10.1126/science.1105959

Journet E., Desboeufs K.V., Caquineau S., et al. 2008. Mineralogy as a critical factor of dust iron solubility. Geophys. Res. Lett. 35: L07805. https://doi.org/10.1029/2007GL031589

Korte L.F., Brummer G.-J., van der Does M., et al. 2016. Compositional changes of present-day transatlantic Saharan dust deposition, Atmos. Chem. Phys. 17: 6023-6040. https://doi.org/10.5194/acp-2016-1068

Maeda N., Noriki S., Narita H. 2007. Grainsize, La/Yb and Th/ Sc of settling particles in the Western North Pacific: Evidence for Lateral Transport of Small Asian Loess. J. Oceanogr. 63: 803-813 https://doi.org/10.1007/s10872-007-0068-8

Mari X., Passow U., Migon C., et al. 2017. Transparent exopolymer particles: Effects on carbon cycling in the ocean. Prog. Oceanogr. 151: 13-37. https://doi.org/10.1016/j.pocean.2016.11.002 
Martinez-Ruiz F., Paytan A., Gonzalez-Muñoz M.T., et al. 2019. Barite formation in the ocean: Origin of amorphous and crystalline precipitates. Chem. Geol. 511: 441-451. https://doi.org/10.1016/j.chemgeo.2018.09.011

Menéndez I., Derbyshire E., Engelbrecht J., et al. 2009. Saharan dust and aerosols on the Canary Islands: past and present. In: Chang M., Liu W. (eds), Airborne Particulates, Nova Publishers Inc., New York, pp. 39-80.

Menéndez I., Derbyshire E., Carrillo T., et al. 2017. Saharan dust and the impact on adult and elderly allergic patients: the effect of threshold values in the northern sector of Gran Canaria, Spain. Int. J. Environ. Health Res. 27: 144-160. https://doi.org/10.1080/09603123.2017.1292496

Michaels A.F., Silver M.W. 1988. Primary production, sinking flux and the microbial food web. Deep-Sea Res. 35: 473-490. https://doi.org/10.1016/0198-0149(88)90126-4

Milliman J.D., Syvitsku J.P.M. 1992. Geomorphic/tectonic control of sediment discharge to the ocean: the importance of small mountainous rivers. J. Geol. 100: 525-544. https://doi.org/10.1086/629606

Montgomery M.T., Welschmeyer N.A., Kirchman D.L. 1990. A simple assay for chitin: application to sediment trap samples from the subarctic Pacific. Mar. Ecol. Prog. Ser. 64: 301-308. https://doi.org/10.3354/meps064301

Müller P., Schneider R. 1993. An automated leaching method for the determination of opal in sediments and particulate matter. Deep Sea Res. 40: 425-444. https://doi.org/10.1016/0967-0637(93)90140-X

Neuer S., Ratmeyer V., Davenport R., et al. 1997. Deep water particle flux in the Canary Island region: seasonal trends in relation to long-term satellite derived pigment data and lateral sources. Deep-Sea Res. I 44: 1451-1466. https://doi.org/10.1016/S0967-0637(97)00034-4

Neuer S., Freudenthal T., Davenport B., et al. 2002. Seasonality of surface water properties and particle flux along a productivity gradient o NW Africa. Deep-Sea Res. II 49: 3561-3576. https://doi.org/10.1016/S0967-0645(02)00098-X

Neuer S., Torres-Padrón M.E., Gelado-Caballero M.D., et al. 2004. Dust deposition pulses to the eastern subtropical North Atlantic gyre: Does ocean's biogeochemistry respond? Global Biogeochem. Cycles 18: 1451-1466. https://doi.org/10.1029/2004GB002228

Okada K., Heintzenberg J., Kai K., et al. 2001. Shape of atmospheric mineral particles collected in three Chinese arid-regions. Geophys. Res. Lett. 28: 3123-3126. https://doi.org/10.1029/2000GL012798

Otosaka S., Togawa O., Baba M., et al. 2004. Lithogenic flux in the Japan Sea measured with sediment traps. Mar. Chem. 91: 143-163. https://doi.org/10.1016/j.marchem.2004.06.006

Pakulski J.D., Benner R. 1994. Abundance and distribution of carbohydrates in the ocean. Limnol. Oceanogr. 39: 930-940. https://doi.org/10.4319/1o.1994.39.4.0930

Passow U. 2000. Formation of Transparent Exopolymer Particles, TEP, from dissolved precursor material. Mar. Ecol. Prog. Ser. 192: $1-11$.

https://doi.org/10.3354/meps192001
Passow U. 2002. Transparent Exopolymer Particles (TEP) in aquatic environments. Prog. Oceanogr. 55: 287-333. https://doi.org/10.1016/S0079-6611(02)00138-6

Pérez C., Haustein K., Janjic Z., et al. 2011. An online mineral dust aerosol model for meso to global scales: Model description, annual simulations and evaluation. Atmos. Chem. Phys. 11: 13001-13027. https://doi.org/10.5194/acp-11-13001-2011

Ratmeyer V., Fischer G., Wefer G. 1999. Lithogenic particle fluxes and grainsize distributions in the deep ocean off northwest Africa: Implications for seasonal changes of aeolian dust input and downward transport. Deep-Sea Res. I 46: 1289-1337. https://doi.org/10.1016/S0967-0637(99)00008-4

Reid E.A., Reid J.S., Meier M.M., et al. 2003. Characterization of African dust transported to Puerto Rico by individual particle and size segregated bulk analysis. J. Geophys. Res. 108: 8591. https://doi.org/10.1029/2002JD002935

Røstad A., Kaartvedt S. 2013. Seasonal and diel patterns in sedimentary flux of krill fecal pellets recorded by an echo sounder. Limnol. Oceanogr. 58: 1985-1997. https://doi.org/10.4319/10.2013.58.6.1985

Sangrà P., Pascual A., Rodríguez-Santana A., et al. 2009. The Canary Eddy Corridor: a major pathway for long-lived eddies in the North Atlantic. Deep-Sea Res I 56: 2100-2114. https://doi.org/10.1016/j.dsr.2009.08.008

Sarnthein M., Thiede J., Pflaumann U., et al. 1982. Atmospheric and Oceanic Circulation Patterns off Northwest Africa During the Past 25 Million Years. In: von Rad U., Hinz K. et al. (eds), Geology of the Northwest African Continental Margin. Springer, Berlin Heidelberg, pp. 545-604. https://doi.org/10.1007/978-3-642-68409-8_24

Souza C.P., Almeida B.C., Colwell R.R., et al. 2011. The importance of chitin in the marine environment. Mar. Biotechnol. 13: 823-830.

Sprengel C., Baumann K.-H., Neuer S. 2000. Seasonal and interannual variation of coccolithophore fluxes and species composition in sediment traps north of Gran Canaria $\left(29^{\circ} \mathrm{N} 15^{\circ} \mathrm{W}\right)$. Mar. Micropaleontol. 39: 157-178. https://doi.org/10.1016/S0377-8398(00)00019-0

Sprengel C., Baumann K.-H., Henderiks J., et al. 2002. Modern coccolithophore and carbonate sedimentation along a productivity gradient in the Canary Island region: seasonal export production and surface accumulation rates. Deep-Sea Res. II 49: 3577-3598 https://doi.org/10.1016/S0967-0645(02)00099-1

Turner J.T. 2015. Zooplankton fecal pellets, marine snow, phytodetritus and the ocean's biological pump. Prog. Oceanogr. 130: 205-248. https://doi.org/10.1016/j.pocean.2014.08.005

van der Jagt H., Friese C., Stuut J.-B., et al. 2018. The ballasting effect of Saharan dust deposition on aggregate dynamics and carbon export: Aggregation, settling, and scavenging potential of marine snow. Limnol. Oceanogr. 9. https://doi.org/10.1002/lno.10779

Wadell H. 1934. Some new sedimentation formulas. J. Appl. Phys. 5: 281-291. https://doi.org/10.1063/1.1745211 